\title{
Concomitant Abdominal Aortic Aneurysm and L2-L3 Disk Herniation: Is There a Relationship Between Them?
}

\section{Abdominal Aort Anevrizması ve L2-L3 Disk Hernisi Birlikteliği: Aralarında Bir ilişki Var Mı?}

\author{
(D) Yakup ERDEN1', iD Rumeysa SAMANCI², iD Elif YAKŞİ1
}

${ }^{1}$ Izzet Baysal Physical Treatment and Rehabilitation Training and Research Hospital, Physical Medicine and Rehabilitation, Bolu, Turkey

2Düzce Atatürk State Hospital, Clinic of Physical Medicine and Rehabilitation, Düzce, Turkey

\begin{abstract}
Abdominal aortic aneurysm (AAA) is a critical disease and is often asymptomatic. It can cause diminished lumbar blood flow. Impaired blood flow in the lumbar arteries is significantly associated with decreased diffusion in lumbar disks and may lead to progressive disk damage. AAA can clinically mimic upper lumbar disk herniation. Disk herniation is rarely seen in the upper lumbar region since the upper part of the lumbar spine is less mobile than the lower region. To the best of our knowledge, no reports have presented concomitant AAA and L2-L3 disk herniation. We describe a 48-year-old man treated for symptomatic AAA followed by L2-L3 disk herniation at an interval of 3 months.
\end{abstract}

Keywords: Low back pain, abdominal aortic aneurysm, disk herniation, disk degeneration

\section{ÖZ}

Abdominal aort anevrizması (AAA) önemli bir hastalıktır ve sıklıkla asemptomatiktir. Lomber kan akısında azalmaya neden olabilir. Lomber arterlerdeki bozulmuş akış, lomber disklerdeki difüzyonun belirgin şekilde azalmasıyla ilişkilidir ve ilerleyici disk hasarına yol açabilir. AAA klinik olarak üst lomber disk hernilerini taklit edebilir. Lomber omurganın üst kısmı alt bölgeden daha az hareketli olduğundan, disk herniasyonu üst lomber bölgede nadiren görülür. Bildiğimiz kadarıyla, literatürde abdominal aort anevrizması ve L2L3 disk herniasyonu birlikteliği ile ilgili daha önce herhangi bir rapor bulunmamaktadır. Biz üç ay arayla semptomatik AAA ve L2L3 disk hernisi nedeniyle tedavi edilen 48 yaşında bir erkek hastayı sunuyoruz.

Anahtar Sözcükler: Bel ağrısı, abdominal aort anevrizması, disk hernisi, disk dejenerasyonu

\section{Introduction}

Low back pain (LBP) is most commonly caused by mechanical dysfunction. However, 1-2\% of cases are caused by nonmechanical spinal disorders or visceral disease, such as abdominal aortic aneurysm (AAA) (1). Factors potentially involved in chronic LBP in patients with AAA include the size of the aneurysm, increased pressure on the vascular wall and surrounding neural elements, and erosion of the vertebral body (2). Several cross-sectional studies have suggested that vascular diseases in the lumbar area are associated with disk degeneration (DD) and LBP (3-5). The correlation of atherosclerotic changes to DD was stronger in the upper levels of the lumbar spine than in the lower ones (5). AAA can cause lumbar DD and clinically mimic upper lumbar disk herniation. The incidence of herniated upper lumbar disks is less than that of lower disks (6). Pathological fractures due to osteoporosis, bone metastasis, and spinal tumors must be 
considered alternatively when assessing upper lumbar pathology. AAA and L2-L3 disk herniation are rarely concomitant, as they were in the present case.

\section{Case Report}

A 48-year-old man, a current smoker, with a previous diagnosis of hypertension first presented with severe localized LBP after walking $200 \mathrm{~m}$. The pain made walking difficult but was relieved by resting for at least $5 \mathrm{~min}$. It persisted for two months and was not ameliorated by analgesics or myorelaxant agents. The pain was rated $9 / 10$ on a visual analog scale (VAS), and the patient reported no night pain or morning stiffness. The patient is a maintenance technician and had moderate physical activity levels. He had no trauma history. At physical examination, the range of motion testing of the lumbar spine was normal but painful, and palpation of the lumbar spinous process segments and paravertebral muscles also elicited pain. The straight leg raise test was negative. The range of motion of the hip joints was normal, and no pain and restriction were detected at the hip joints in the flexion-abduction-external rotation test and flexionadduction-internal rotation test. Sacroiliac joint provocation tests were negative. Gait analysis was normal, and no pelvic asymmetry was detected. Neurological examination was unremarkable, and the patellar reflex was normoactive. Arterial pulses in the lower limbs were normal. Edema, leg diameter difference, and discoloration were not observed in the lower extremities. The patient did not report systemic symptoms such as fever, muscle pain, fatigue, or weight loss. Results of the systemic examination were normal. The patient had not sought medical assistance for any systemic disease, except for hypertension. Results of laboratory investigations (such as complete blood count, erythrocyte sedimentation rate, and C-reactive protein) were within the normal limits. Magnetic resonance imaging (MRI) revealed a thrombosed aneurysmatic dilatation $(68 \times 60 \mathrm{~mm}$ in the widest part) of the wall in an approximately $12 \mathrm{~cm}$ segment of the abdominal aorta and L2-3 left paracentral extruded disc herniation with lateral recess stenosis. Loss of signal intensity due to degeneration was also detected in the intervertebral discs and more markedly in the upper lumbar disks (Figure 1). The patient was referred to the cardiovascular surgery department where an endovascular stent graft was inserted in the aortoiliac position (Figure 2). No complication was observed during or after the intervention, and the clinical symptoms improved significantly. Following surgery, the patient started walking $30 \mathrm{~min}$ to $1 \mathrm{~h}$ daily. At six weeks following surgery, the patient did not report any episodes of low back or abdominal pain.

Three months later, the patient was readmitted to our clinic again with LBP extending to the left lower extremity. Physical examination revealed tenderness over the lumbar spinous process segments, and the femoral nerve stretch test was positive on the left side. The lumbar lordosis had decreased, and antalgic gait was present. The cardiovascular surgery department was consulted in terms of contraindication before treatment. Since the case was compatible with discogenic LBP, 15 sessions of physiotherapy including superficial and deep heating and burst- type transcutaneous electrical nerve stimulation were applied. McKenzie and stabilization exercises were performed. The radiating LBP improved, and the VAS score decreased from 8 to 2 points.

\section{Discussion}

The pathogenesis of LBP is multifactorial. AAA can induce LBP. It is mainly caused by arterial stenosis, which results in the reduction of blood flow in the affected area. Initially, no symptoms were observed at rest, but patients may experience claudication during exercise. It may also play an important role in the mechanism of painful degenerative disc diseases. In this case, the patient presented early with claudication and lately with lower radiating back pain.

AAA is defined as a weakening of the aortic wall involving progressive, full-thickness local dilation $>150 \%$ of the normal diameter. Diameters exceeding $3 \mathrm{~cm}$ are clinically significant. Larger aneurysms expand at a faster rate than smaller aneurysms. The risk of spontaneous rupture increases exponentially with

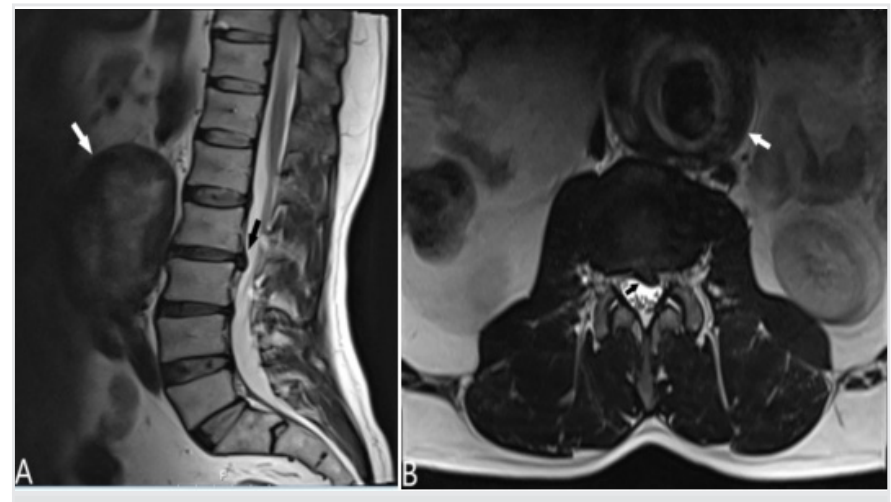

Figure 1. Preoperative T2-sagittal (A) and T2-axial (B) magnetic resonance images showing abdominal aortic aneurysm (AAA) (white arrow) and L2-3 extruded disk herniation (black arrow)



Figure 2. Postoperative sagittal (A) and axial (B) computed tomography (CT) angiography sections showing stent material in the abdominal aorta starting from the renal level and extending into both the common iliac arteries. In contrast to the upper vertebral arteries, the second pair of the lumbar arteries did not appear normal 
the aortic diameter. Rupture accounts for more than $40 \%$ of mortality cases (7). Thus, surgery is generally recommended when the AAA exceeds $>5.5 \mathrm{~cm}$ in diameter in men and $>5.0$ $\mathrm{cm}$ in women, in the presence of symptoms, and in the case of a rapid increase in size (8). In the present case, endovascular aneurysm repair was performed since the risk of rupture was high and symptoms developed. Previous studies have suggested that arterial surgery (when possible) is effective for LBP symptoms in patients with AAA (9).

Although the etiology of an AAA is still not completely understood, major risk factors for an AAA include hypertension, age $>60$ years, male gender, smoking history, atherosclerosis, coronary artery disease, and a genetic/family history of AAA (10). AAA is not normally screened for unless the patient has these specific risk factors. In a male patient aged $>60$ years with one or more additional risk factors, abdominal ultrasonography is initially recommended. In the present case, AAA had been diagnosed incidentally during the investigation of other spinal pathologies.

Autopsy and radiology studies have documented a correlation between vascular disease and DD. Lumbar artery stenosis is significantly associated with decreased diffusion of the lumbar disks. Intervertebral discs receive nutrients by diffusion mainly through the vertebral endplates. Diminished blood flow to the vertebrae may therefore reduce diffusion of nutrients and oxygen to the disk and hamper the disposal of harmful metabolites. Beckworth et al. (11) also found an association with other degenerative changes such as facet arthritis and lumbar canal stenosis. Interestingly, the correlation was strongest in patients aged $\leq 61$ years. Various contributing factors may emerge with advancing age. Similar to vascular diseases, DD begins early in life. Asymptomatic individuals therefore commonly exhibit degenerative changes (12). Trompeter and Paremain reported a case series of four patients who had incidental AAA detected on lumbosacral MRI. All patients had degenerative spinal diseases. Kim et al. (13) reported a case in which AAA with mural thrombus coexisted with aggravated L3-L4 intervertebral disc extrusion. Surgery was performed for both pathologies in that case (14).

The upper three segments of the lumbar spine are supplied only by the segmental lumbar arteries, originating from the posterior wall of the abdominal aorta. The L1, L2, and L3 arteries mainly go to the L1-2, L2-3, and L3-4 disk spaces, respectively. Stenosis of the ostia of the lumbar arteries may trigger degenerative changes. With its location at the end of the nutrient chain, the disk is affected earliest by poor circulation. Insufficient blood supply may render the disks more vulnerable to mechanical stress and thus result in disk damage (5). AAA is frequently associated with diminished lumbar blood flow, and 95\% of AAAs are located in the infrarenal region (L1-4 level). The prevalence of complicated lesions associated with atheromatous plaques (i.e., plaques with necrosis, thrombus, and calcification) increases rapidly at age 44-65 years. Either atheromatous plaques or thrombotic layers accumulate gradually inside the aneurysm. This then gradually obstructs the corresponding lumbar arteries but allows sufficient time for collateral pathways to develop. Therefore, ischemic symptoms in the lumbar region are rarely found even after AAA surgery. Symptoms may be observed only during exertion when reduced blood supply fails to meet demand (15). In the present case, degeneration was particularly marked in the upper lumbar disks, and symptoms developed following exertion.

The upper lumbar disks are generally defined as the L1-L2 and L2-L3 levels. Disk herniation is rarely seen in this region since the upper part of the lumbar spine is less mobile than the lower region. Upper lumbar disk herniations constitute 1-2\% of all herniated lumbar disks and are mostly seen in the older population (16). Clinical signs associated with upper lumbar disk herniation are nonspecific, with most patients reporting low back and leg pain. The radicular pattern of back pain may not be clear and not reflect the true level of the disease. The femoral nerve stretch test, also known as reverse straight raise test, is positive in $84-95 \%$ of the patients with upper lumbar disk herniation, as in the present case (17). The nerve root in the upper lumbar spine does not innervate any specific muscles. In some cases, the clinical signs of radiculopathy do not match the electromyographic signs, so electromyography has no absolute diagnostic value. Accurate diagnosis is often difficult without radiological findings. Surgical outcomes of upper lumbar disk herniation are less satisfactory than those involving lower disks (18). Therefore, conservative treatment was applied in the present case. In the management of patients with upper lumbar degenerative disk diseases, the possibility of comorbidities such as an AAA should not be overlooked because a delayed diagnosis of AAA puts the patient at risk of aneurysmal rupture.

AAA is a rare entity that may be asymptomatic. An advanced disease has been correlated with LBP and DD, in which a degenerative "cascade" of events is triggered. A gradual decrease in disk flexibility and increased ruptures in annulus fibrosis may lead to herniation of the nucleus pulposus. AAA can therefore present with localized back pain or radiculopathy. Further studies are needed to confirm the causal association.

\section{Ethics}

Informed Consent: An informed consent was obtained from the patient.

Peer-review: Externally peer reviewed.

\section{Authorship Contributions}

Surgical and Medical Practices: Y.E., R.S., Concept: Y.E., R.S., E.Y., Design: Y.E., R.S., E.Y., Literature Search: Y.E., E.Y., Writing: Y.E., E.Y.

Conflict of Interest: No conflict of interest was declared by the authors.

Financial Disclosure: The authors declared that this study received no financial support. 


\section{References}

1. Jarvik JG, Deyo RA. Diagnostic evaluation of low back pain with emphasis on imaging. Ann Intern Med 2002;137:586-97.

2. Tsuchie H, Miyakoshi N, Kasukawa Y, Nishi T, Abe H, Takeshima $\mathrm{M}$, et al. High prevalence of abdominal aortic aneurysm in patients with chronic low back pain. Tohoku J Exp Med 2013;230:83-6.

3. Kurunlahti M, Tervonen O, Vanharanta H, Ilkko E, Suramo I. Association of atherosclerosis with low back pain and the degree of disc degeneration. Spine (Phila Pa 1976) 1999;24:2080-4.

4. Kurunlahti M, Karppinen J, Haapea M, Niinimäki J, Autio R, Vanharanharanta $\mathrm{H}$, et al. Three-year follow-up of lumbar artery occlusion with magnetic resonance angiography in patients with sciatica: associations between occlusion and patient-reported symptoms. Spine (Phila Pa 1976) 2004;29:1804-8.

5. Kauppila LI, Penttilä A, Karhunen PJ, Lalu K, Hannikainen P. Lumbar disc degeneration and atherosclerosis of the abdominal aorta. Spine (Phila Pa 1976) 1994;19:923-9.

6. Adamec I, Prutki M, Habek M. Abdominal aortic aneurysm mimicking L2-L3 disc herniation. Acta Neurol Belg 2016;116:695-7.

7. Sakalihasan N, Limet R, Defawe OD. Abdominal aortic aneurysm. Lancet 2005;365:1577-89.

8. Kent KC. Clinical practice. Abdominal aortic aneurysms. N Engl J Med 2014;371:2101-8.

9. Takeyachi Y, Yabuki S, Arai I, Midorikawa H, Hoshino S, Chiba $\mathrm{K}$, et al. Changes of low back pain after vascular reconstruction for abdominal aortic aneurysm and high aortic occlusion: a retrospective study. Surg Neurol 2006;66:172-6.
10. Forsdahl SH, Singh K, Solberg S, Jacobsen BK. Risk factors for abdominal aortic aneurysms: a 7-year prospective study: the Tromsø Study, 1994-2001. Circulation 2009;119:2202-8.

11. Beckworth WJ, Holbrook JF, Foster LG, Ward LA, Welle JR. Atherosclerotic Disease and its Relationship to Lumbar Degenerative Disk Disease, Facet Arthritis, and Stenosis With Computed Tomography Angiography. PM R 2018;10:331-7.

12. Miller JA, Schmatz C, Schultz AB. Lumbar disc degeneration: correlation with age, sex, and spine level in 600 autopsy specimens. Spine (Phila Pa 1976) 1988;13:173-8.

13. Kim NS, Kang SH, Park SY. Coexistence of expanding abdominal aortic aneurysm and aggravated intervertebral disc extrusion -a case report-. Korean J Anesthesiol 2013;65:345-8.

14. Trompeter AJ, Paremain GP. Incidental abdominal aortic aneurysm on lumbosacral magnetic resonance imaging - a case series. Magn Reson Imaging 2010;28:455-7.

15. Kauppila LI. Atherosclerosis and disc degeneration/low-back pain--a systematic review. Eur J Vasc Endovasc Surg 2009;37:661-70.

16. Kim DS, Lee JK, Jang JW, Ko BS, Lee JH, Kim SH. Clinical features and treatments of upper lumbar disc herniations. J Korean Neurosurg Soc 2010;48:119-24.

17. Porchet F, Fankhauser H, de Tribolet N. Extreme lateral lumbar disc herniation: clinical presentation in 178 patients. Acta Neurochir (Wien) 1994;127:203-9.

18. Karaaslan B, Aslan A, Börcek AÖ, Kaymaz M. Clinical and surgical outcomes of upper lumbar disc herniations: a retrospective study. Turk J Med Sci 2017;47:1157-60. 